\title{
Gold Production at the Rand Refinery
}

\section{COMPLETION OF THE MODERNISATION PROGRAMME}

After fifty years of operation under increasingly heavy pressure, the equipment and buildings of the Rand Refinery have been completely modernised and now constitute virtually an entirely new and up-to-date plant. It can now treat the mines' total annual production of over 32,000,000 ounces with capacity to spare.

Some fifty major gold mines and about a dozen smaller ones in South Africa produce well over $30,000,000$ ounces of gold a year - more than 70 per cent of the free world's supply of newly mined metal. The product of the mines contains only about 88 per cent gold, 10 per cent of silver and 2 per cent of base metals, chiefly copper, lead and zinc, and all this output has therefore to be refined. To handle this operation the Rand Refinery, a subsidiary of the Chamber of Mines of South Africa, was established in 1920 at Germiston, some ten miles east of Johannesburg.

Rand Refinery Limited is a non-profit service company whose members are the South African gold mining companies that constitute the Chamber of Mines. The whole complex comprises

The crude gold bars arriving from the mines contain only about 88 per cent of gold. They are meltel in a battery of six induction furnaces and cast into ingots for refining. a gold refinery, a silver refinery and a smelting section for the treatment of by-products. A staff of 175 Europeans and 225 Bantu is employed.

This refinery was originally designed to deal with a maximum of about 12,000,000 fine ounces of gold a year, but the trend of production since then has, of course, been fairly steadily upwards and by 1965

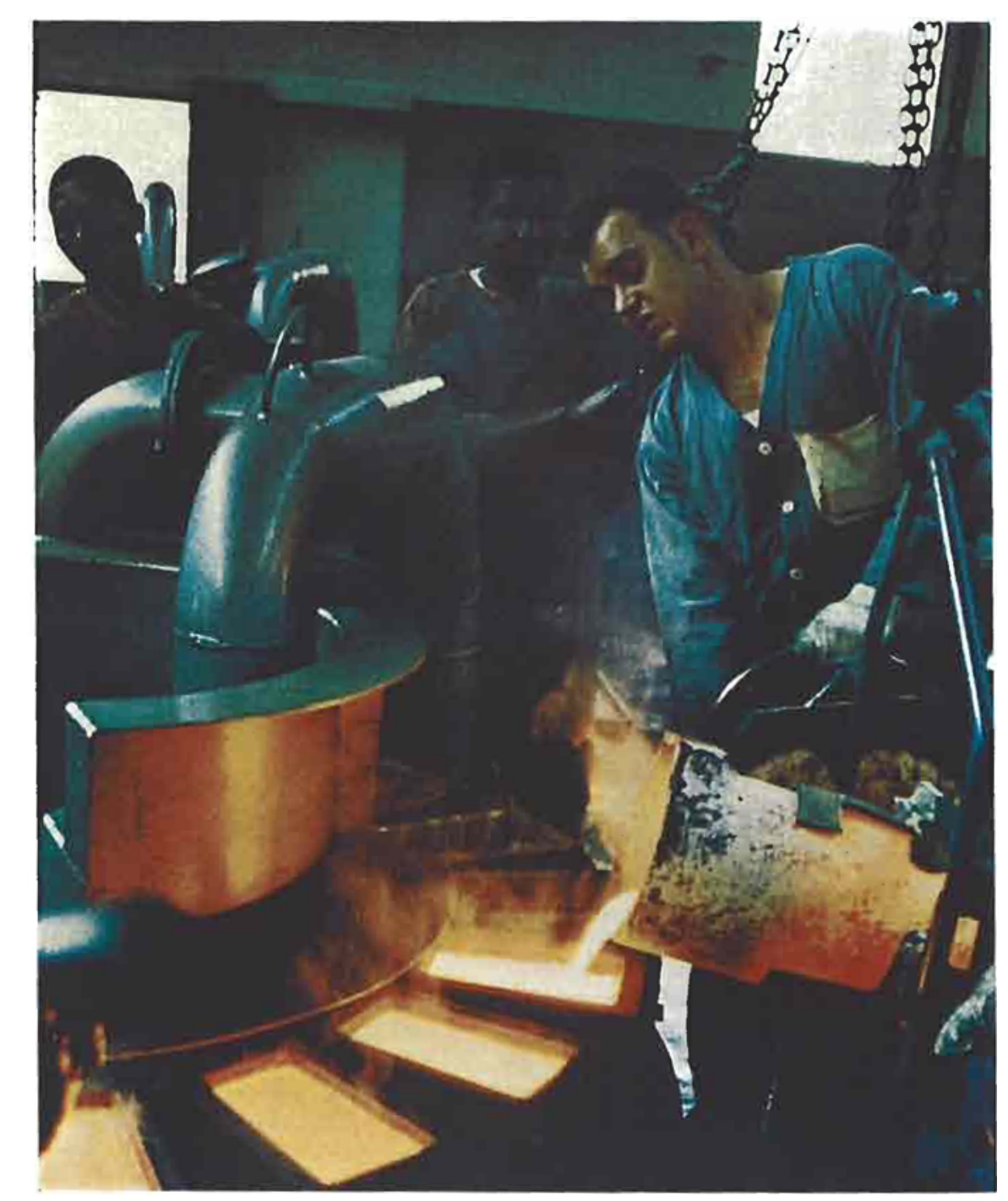




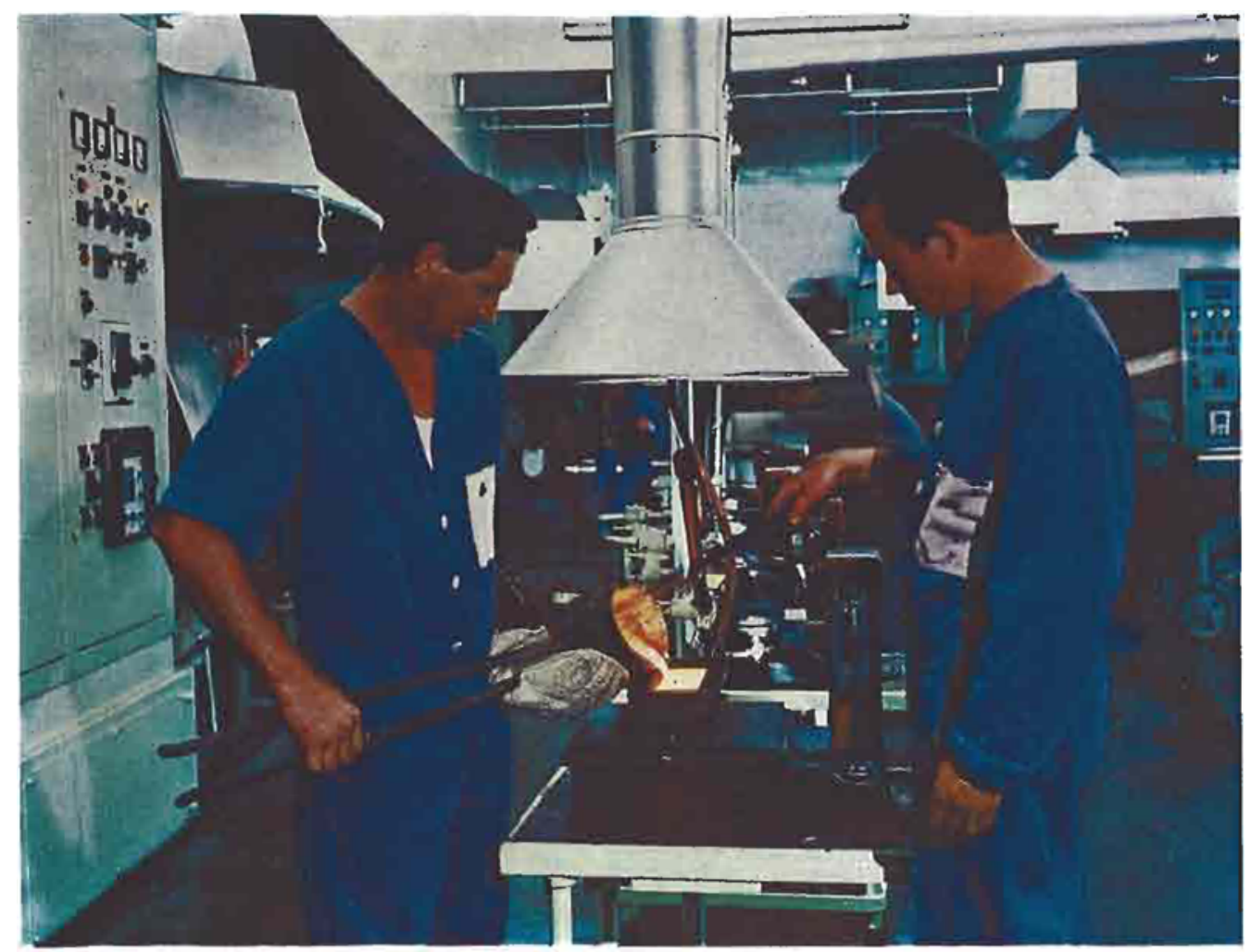

After chlorine refining, the gold, now of 99.6 per cent purity, is cast into $12.5 \mathrm{~kg}$ ( 400 ounce) bars. The furnace installation in the refinery consists of seven half-ton $150 \mathrm{~kW}$ induction refining furnaces and two one-ton $225 \mathrm{~kW}$ holding furnaces.

South Africa's gold mines were producing $30,000,000$ ounces annually - almost three times the initial designed capacity of the refinery - and although operations had been continually modified and expanded it then became necessary to embark on a major programme of modernisation.

This programme was recently completed at a cost of nearly $R 4,000,000$ and the modernised refinery is now capable of extracting the silver and other by-products from the gold sent in from the mines and of producing over $32,000,000$ ounces of gold, with spare capacity to refine a further 25 per cent of this production figure. It is of course the world's largest gold refinery.

The crude gold bars arriving from the mines are of standard shape and weigh about $31 \mathrm{~kg}$ or 1,000 ounces each. After weighing and sampling these are melted in graphite crucibles in a battery of six 100 $\mathrm{kW}$ induction furnaces and cast into ingots of $12.5 \mathrm{~kg}$ each on a casting wheel. After assaying, these ingots are transferred to the refinery. Here the procedure used is the well-known chlorine process originally devised by F. B. Miller of the Sydney Mint in 1867. Chlorine is bubbled through the molten gold to attack the other metals, and the chlorides of silver, copper, zinc and other base metals then float to the surface and can readily be removed, leaving gold of 99.6 to 99.7 per cent purity in the crucible. The new furnaces in this section of the refinery - replacing a large number of small units - comprise seven half-ton induction refining furnaces and two oneton holding furnaces to which the charges are transferred by means of pre-heated ladles. From these holding units the gold is cast into bars weighing $12.5 \mathrm{~kg}$ or 400 ounces each. These bars are then cleaned, weighed and stamped, ready for shipment.

The numerous improvements to the refinery have resulted in a reduction of the average time for refining, so that the complete cycle from reception to shipment now takes only four days instead of eight as in the past.

One other major improvement included in the modernisation programme is an electrolytic refinery. While gold of 99.6 per cent purity is acceptable for monetary purposes, a higher purity is often required by industrial users and although a number of commercial gold refiners in other parts of the world have facilities for the production of high purity gold, the Rand Refinery is now also in a position to supply this need. This new section employs the Wohlwill process for refining gold by electrolysis. Gold anodes are cast from one of the holding furnaces and are electrolysed in a gold chloride solution, yielding high purity gold -99.99 per cent - on the 


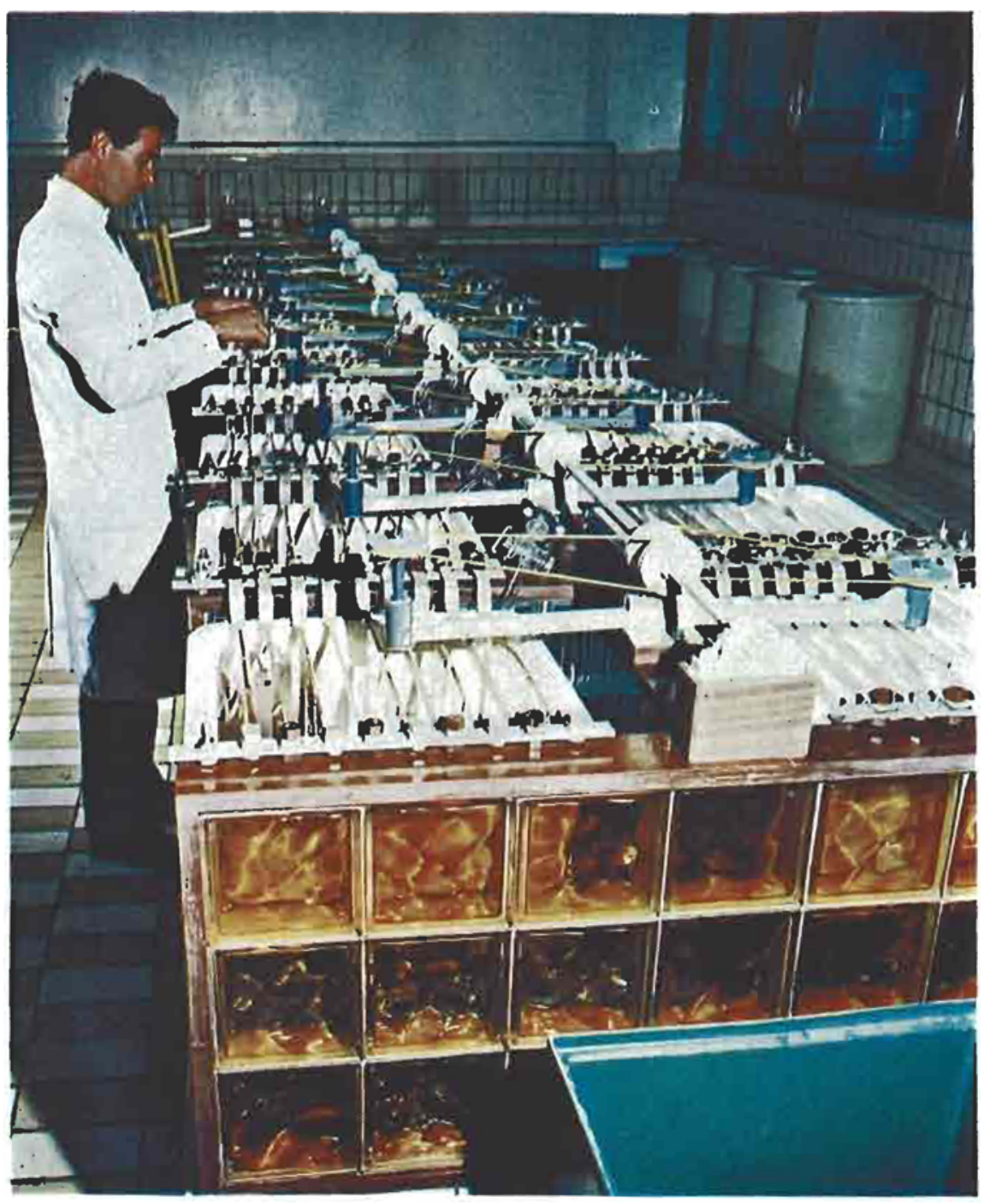

A small electrolytic refinery has been installed in the new plant to produce gold of 99.99 per cent purity for specialiged industrial uses.

cathodes. The initial installation comprises a bank of eighteen cells in normal operation with six others for special purposes. Provision has been made for electrolyte circulation, thermostatic control, mechanical agitation and adequate cathode washing facilities. The importance of this new facet of the refinery's operations can be assessed from the fact that it is estimated that the demand for gold for non-monetary purposes is already equal to world production and is still rising.

\section{Oxygen Coatings on Gold}

In gold refineries it is widely recognised that ingots newly stripped from moulds may weld together so that they become as one if they are piled one on another while still hot. A favourite explanation for this is that the gold is so soft that the mating surfaces flow so as to touch at every point, valley and high spot in one ingot corresponding with high spot and valley in the other.

This, however, cannot be the whole story. Gold is not so hard at room temperature that equally good contact cannot be secured over a large proportion of the contact area under quite light loads; yet in these conditions, when the gold has cooled, no significant welding is found.

The reason for this is almost certainly that normally in air all gold surfaces are covered with a layer of oxygen which acts as a barrier to perfect welding. The attraction of a gold surface for oxygen at normal temperatures is certainly not large; but it is fascinating to reflect that although air contains only a fifth part by volume of oxygen, a gold surface nevertheless takes the oxygen to itself and rejects the nitrogen absolutely.

The circumstances that govern the nature of the bond-whether the coating is one of a single layer of adsorbed atoms or molecules or whether there is oxide formation-are still not clearly defined. One fact that has been shown conclusively, however, is that invisible surface layers of $\mathrm{Au}_{2} \mathrm{O}$ or $\mathrm{AuO}$ can easily be formed by anodic oxidation at a low voltage in dilute sulphuric acid solution. Several stages have been recognised. The first is the formation of a partial layer of oxygen atoms adsorbed on the surface. On further electrolysis this converts to a layer of $A_{2} \mathrm{O}$ and this in turn converts to AuO.

In normal surroundings of moist air, the most that will occur is the attraction of molecules to the surface, with perhaps some ionisation. The film undoubtedly forms very quickly, but it is easily decomposed and vanishes completely when the gold is heated above about $200^{\circ} \mathrm{C}$. And so a newly cast ingot may be expected to have a noble chemically clean surface until it is cool enough to handle. J. C. C. 